\title{
Employment Status of College of Teacher Education Graduates: Basis for an enhanced Teacher Training Program
}

\author{
Dr. Henly F. Martirez, Dr. Evelyn A. Sunico, Dr. Julie Rose P. Mendoza \\ Mr. Freddie Javiña, A/Prof. Marie Ann Gonzales \\ Faculty, Laguna State Polytechnic University, Santa Cruz, Laguna, Philippines
}

\begin{abstract}
One critical measure of success in workplaces is an employee's ability to use competently the knowledge, skills and values that match the needs of his job, satisfy the demands of his employer, and contribute to the overall achievement of institutional goals.

This study shows the Employment Status of College of Teacher Education Graduates from batch 2017, 2018 and 2019, there were a total of 1276 respondents representing the groups of employed, unemployed and not tracked. The response will serve as basis for an enhancement teacher training program and revision/modification/improvement of the existing program of the college of teacher education, , it sought to answer the following evaluation questionnaire (1) Current Employment Status; (a) Employed (b) Presently not employed but seeking for work (c) Reason (s) for staying on the job (d) Reasons for changing job (e) Never employed (2) Jobseekers Experiences (a) What strategies you've made in finding job? (b) What are the difficulties you experience in looking/searching for a job? (c) After you were able to find a vacancy, what are the possible reasons why you did not get the job? (3) Enhancement of Teacher Training Program. The questionnaire was used in the survey questions. The statistical treatment used was open ended.
\end{abstract}

Based on the gathered data of this study, the findings of this study were the following: (1) Current Employment Status. The accumulated percent of the current employment status in terms of Employed was 75.91\% with verbal interpretation Agree, $24.09 \%$ was Disagree and 0\% was Neutral. The accumulated percent of the current employment status in terms of presently not employed but seeking for work was 75.68\% with verbal interpretation Agree, $22.98 \%$ was Disagree and $0.53 \%$ was Neutral. The accumulated percent of the current employment status in terms of Reasons for changing job was $67.3 \%$ with verbal interpretation Agree, $\quad 8.85 \%$ was Disagree and $17.09 \%$ was Neutral. The accumulated percent of the current employment status in terms of Reasons for changing job was $54.7 \quad 3 \%$ with verbal interpretation Agree, $3.23 \%$ was Disagree and $13.95 \%$ was Neutral. The accumulated percent of the current employment status in terms of never employed was $26.65 \%$ with verbal interpretation Agree, 59.25\% was Disagree and $14.11 \%$ was Neutral. (2) Jobseekers Experiences. The accumulated percent of the jobseekers experiences in terms of what strategies you've made in finding job? Was $51.98 \%$ with verbal interpretation Agree, $38.31 \%$ was Disagree and $14.89 \%$ was Neutral. The accumulated percent of the jobseekers experiences in terms of what are the difficulties you experience in looking/searching for a job? Was $54 \%$ with verbal interpretation Agree, $27.44 \%$ was Disagree and $16.61 \%$ was Neutral. The accumulated percent of the jobseekers experiences in terms of after you were able to find a vacancy, what are the possible reasons why you did not get the job was $48.71 \%$ with verbal interpretation Agree, 32.28 was Disagree and $19.05 \%$ was Neutral. (3) Enhancement of Teacher Training Program. The accumulated percent of the enhancement of teacher training program was $44.82 \%$ with verbal interpretation Agree, $\quad 50.24 \%$ was Disagree and $4.95 \%$ was Neutral.

In the Figure shows the employment status of college of teacher education in the year of 2017 with the total number of 528 graduate students and total number of traced employed was 476 or $94 \%$ of the total number, those not tracked was 52 or $6 \%$ of the total number. College of Teacher Education the year of 2018 total number of graduates was 428 students total number of traced employed 413 or $86.63 \%$ total number of 
traced unemployed was 2 or $3.17 \%$ and total number not tracked was 13 or $6.48 \%$. College of Teacher Education the year of 2019 total number of graduates was 320 students total number traced employed was 97 or $25.03 \%$ total number of traced unemployed was 30 or $14.71 \%$ and total number of not tracked was 193 or $61.08 \%$.

Keywords: Employability, Employment Profile, CTE graduates, College of Teacher Education

\section{IMPORTANCE OF THE PROBLEM}

The Employment Status of College of Teacher Education Graduates from batch 2017, 2018 and 2019, the response will serve as basis for an enhancement teacher training program and revision/modification/improvement of the existing program of the college of teacher education.

1. Current Employment Status

a. Employed

b. Presently not employed but seeking for work

c. Reason (s) for staying on the job

d. Reasons for changing job

e. Never employed

2. Jobseekers Experiences

a. What strategies you've made in finding job?

b. What are the difficulties you experience in looking/searching for a job?

c. After you were able to find a vacancy, what are the possible reasons why you did not get the job?

3. Enhancement of Teacher Training Program

\section{LITERATURE}

In the study conducted by Lalican (2007) she emphasized that the acquisition of knowledge in the undergraduate specialixzation skills and competence will also promote productivity, efficiency and expertise in the graduate present job.

On the number employed and unemployed (Deistro, 2013) most of the graduates are employed on the course they finished while those who did not land a job mentioned the following reasons; busy as a houisewives and persue to higher studies (Masteral and Doctoral).

Sawyer (2008) mentioned that tracer studies as surveys of graduates from institution of higher education are often seen as a important tool of institutional development especially when the world of work condition, and their respective assessment of their course of circular debates and could also be interesting for the current or later students.

Manalo(2010) emphasized in this article ' Enhancing the Value of Public Education' that the area are a dozen good reasons for a school to track its alumni and stay in regular contact with them. Colleges and universities both public and private have been tracking alumni for many years. Private schools do as well. He observed that many public schools are all about following their graduate sand he marked this as "golden opportunity wasted".

The above mentioned literature are related to the present study because one of the objectives of the study is to trace the doctoral graduates if they are employable.

In Indonesia, contrary to what is happenig in developed countries, academic efforts connected to the interdependence of higher education where the workplace have not been paid significant attention. On the other hand, the competency of university graduates is experiencing a shift towards a greater awareness on the importance of generic and manegerial competencies, besides specific and technical competencies.

Tracer study is currently incorporated as part of higher education accreditattion system in Indonesia and thus has beeb recently prioritized as important activity of higher education institution. Tracer study is an important indicator of quality university management. The objectives of the tracer study were to obtain information on alumni characteristcs, their current activities, employment and work, and labor market signal. The study also analyzed tracer study situation in 
Indonesia Universities.

Angelo (2005) stated that in assessing the institutional system can help individual focus their collectives attention, examine their assumptions, and create a shared academic culture dedicated to assuring and improving the quality of higher education.

It is true that to examine the effectiveness of the programs through assessing the learning quality as well as learned skills applied in their present profession is remarkable.

Schomburg (2005) claimed that the overall job satisfaction of the graduates is wih the professional situation with different characteristics of employment and the extent of the used of the acquired knowledge and skills added aspect of effectiveness in responding to the changing world of work.

Raquesa D. Macaraub,” Employment Motivation of Selected Media Fractitioners. In Legaspi City the study showed that respondents were motivated to work due to good relationship with their office mates, media practitioners are the lowest paid workers and are exploited, some are not receiving regular salary only allowance or talent fee, ans are required to solicit advertisement for their salary.

Carreras and Durante (2007) tracer's study aimed to find out the employability of Secondary Teacher Education (BSED) programs graduates of the Camarines Sur Polytechnic College in terms of their acquired competencies. Results showed that most of the graduates are from outside Naga City, they are cursuing their master degree and LET passers. They are also active in churh related and other community activities. As to employment, some of them, are fully employed in locally, nationally funded agencies or overseas; enjoy permanent status. Graduates as well as the employees agrees that they manifest skills in problem solving and decision making communication interaction, professional demeanor and leadership also among the professional competencies, personal qualities was the most manifested followed by relationship with others, then technological adaptability.

The presents research is varies in scope compared with the above related study. The objectives of the presents study is to determined the personal and professional status of doctor of education students and their professional fulfillment.

According to Yoke and Knight (2004) it is true that employability is seen to be influenced, on students' self efficay beliefs , student's self-theories and personal qualities. They said that the extent to which students feel that they can make a difference. It is importantly, to include a wider range attributes required to be successful within employment but also includes that attributes required to manage one's career development in ways that will sustain one's employability.

According to Nabi (2003) employability is about graduates possessing an appropriate level of skills and attributes , and being able to use them to gain and remain in appropriate employment. Employability is a promise to employess that they will have the skills to find new jobs quickly if their jobs and unexpectedly (Baruch ,2001). Prior to this, Harvey (2001) has defined employability in various ways from individual and institutional perspectives. Individual employability is defined as graduates being able to demonstrate the attributes to obtain jobs.

\section{INTRODUCTION}

The best quality education for the holistic development of future teachers in the elementary and secondary levels. Its primary concern as a teacher education institution is the preparation of globally competitive teachers and are imbued with $21^{\text {st }}$ century skills and values relevant to the needs of the times. Its focus on quality and excellence is reflected in its vision, goals, curricular and instructional practices, learning resources provided, management scheme and in its program, and outcomes assessment systems.

In achieving the goals of higher education, all actions are geared towards strengthening the higher education system to enhance its capability to perform its fundamental role in nation building, and respond to global development and challenges.

One of the requirement for quality education in higher education is the consideration of different perspectives to assure quality of teaching and learning. In this viewpoint, tracer study of the employability of Graduates 2016 was conducted.

Tracer study are important as a way of understanding the relevance and quality of programs offered by the Universities as well as the industries and/or labor market (Obando and Shisanya, 2013). A need for practical and real evidence concerning the professional relevance of Higher Education Institutions (HEIs) study programs using graduate tracer studies. HEIs require tracer studies for accreditation of curricular offerings and/or programs offered by the University as well as for SUC leveling purposes. Higher Education Institutions are interested in feedback from their graduates on the quality of education they received during their schooling.

Since LSPU people are committed with continual improvement providing quality, efficient services to the students and other stakeholders with highest level of satisfaction, this tracer is very significant. An author Ron Lewis (brainy quote, 2001) once mentioned that, "ensuring quality higher education is one of the most important things we can do for future 
generations". This is the very reason why this tracer study is made to find out how far is LSPU in providing quality education to the stakeholders. Moreover, find out that if the graduates of all campuses have significant difference in terms of employability percentage for the recent years (2013-2016). The result of this employability assessment/evaluation would help and benefit the following:

Providing quality education to students is the mission of every institution. It is the aspiration of every individual to get the best learning they can have in an educational institution that will hone individual's skills and unleash the talents and potentials within. Evaluating services provided by an institution is customarily measured in terms of employability of graduates.

Employability of graduates is a major success indicator of curriculum effectiveness (Lopena G. 2012). It is also a determinant how effective and efficient the instruction, knowledge, and development given to the students. What to improve in the room of education could be determined through an organized procedure of assessing its services and programs such as the conduct of tracer studies and/or employability of graduates of an institution (Anayoc, R. 2014).

To the Filipinos, knowledge is acquired through education. It is generally agreed that education can be obtained inside and outside schools. Thus, the higher a person achieve on the formal educational ladder, the more he/she attains knowledge and expectedly acquires more employment opportunities. The importance of education is basically for two reasons. The first is that the training of a human mind is not complete without education. Education makes a man right thinker. It tells man how to think and make decisions. The second reason for the importance of education is that only through the attainment of education; man is enabled to receive information from the external world; acquaint him with past history and receive all necessary information regarding the present. Laguna State Polytechnic University is one of the universities in the Philippines that caters people from all walks of life. Students who are inclined in technology, fishery, agriculture and education are the main target of the institution. Its mission is to provide quality education through responsive instruction, distinctive research and sustainable extension and production services for the improvement of the quality of life of the stakeholders towards nation-building. Thus, this university hopes to be the center of sustainable development, transforming live and communities. In support to this aspiration, LSPU Campuses are in consonance with the vision and mission of the university, that's why this study on employability status of the graduates was conducted. Without education, man is through in a closed room and with education he finds himself in prospective employees to be well educated. They require expertise. So, education becomes an eligibility criterion form employment into any sector of the industry. We are rewarded for exercising expertise required

\section{METHODOLOGY}

Employment Status in College of Teacher Education the year of 2017 total number of graduates was 528 students total number of traced employed was 476 or $94 \%$ and total number of not tracked was 52 or $6 \%$. College of Teacher Education the year of 2018 total number of graduates was 428 students total number of traced employed 413 or $86.63 \%$ total number of traced unemployed was 2 or $3.17 \%$ and total number not tracked was 13 or $6.48 \%$. College of Teacher Education the year of 2019 total number of graduates was 320 students total number traced employed was 97 or $25.03 \%$ total number of traced unemployed was 30 or $14.71 \%$ and total number of not tracked was 193 or $61.08 \%$.

Data for the number of graduates by degree and by batch were obtained from the registrar's office while data for the traced graduates were gathered by the alumni affairs office through the use of the a graduate tracer form, social media, phone calls and personal interviews.

\section{RESULT AND DISCUSSION}

\section{Employment Status of College of Teacher Education Graduates from batch 2017, 2018 and 2019}

Frequency distribution number of Employed, Unemployed and Not Tracked in College of Teacher Education from batch 2017.

Bachelor of Industrial Education major in Drafting Technology total number of graduates was 1 student and total number of traced employed was 1 or $100 \%$. Bachelor of Industrial Education major in Home Economics total number of graduates was 26 students and total number of traced employed was 21 or $80.77 \%$ and total number of not tracked was 5 or $19.23 \%$. Bachelor of Industrial Education major in Industrial Arts total number of graduates was 5 students and total number of traced employed was 5 or $100 \%$. Bachelor of Secondary Education major in Bio Science total number of graduates was 20 students and total number of traced employed was 16 or $80 \%$ and total numbers of not traced was 4 or $20 \%$. Bachelor of Secondary Education major in English total number of graduates was 56 students and 
total number of traced employed was 49 or $87.5 \%$ and total number of not tracked was 7 or $12.5 \%$. Bachelor of Secondary Education major in Filipino total number of graduates was 47 students and total number of traced employed was 44 or $93.62 \%$ and total number of not traced was 3 or $6.38 \%$. Bachelor of Secondary Education major in MAPEH total number of graduates was 33 students and total number of traced employed was 27 or $81.82 \%$ and total number of not traced was 6 or $18.18 \%$. Bachelor of Secondary Education major in Mathematics total number of graduates was 47 students and total number of traced employed was 38 or $80.85 \%$ and total number of not traced was 9 or $19.15 \%$. Bachelor of Secondary Education major in Physical Science total number of graduates was 13 students and total number of traced employed was 11 or $84.62 \%$ and total number of not traced was 2 or $15.38 \%$. Bachelor of Secondary Education major in Social Science total number of graduates was 51 students and total number of traced employed was 42 or $82.35 \%$ and total number of not traced was 9 or $17.65 \%$. Bachelor of Secondary Education major in TLE total number of graduates was 23 students and total number of traced employed was 23 or $100 \%$. Bachelor of Elementary Education major in General Education total number of graduates was 48 students and total number of traced employed was 42 or $87.5 \%$ and total number of not traced was 6 or $12.5 \%$. Bachelor of Elementary Education major in Pre-Elem. Education total number of graduates was 13 students and total number of traced employed was 12 or $93.31 \%$ and total number of not traced was 1 or $12 \%$. Bachelor of Elementary Education major in SPED total number of graduate was 1 student and total number of traced employed was 1 or $100 \%$. Certificate in Teaching Proficiency total number of graduates was 8 students and total number of traced employed was 8 or $100 \%$. Master Teacher major in English total number of graduates was 6 students and total number of traced employed was 6 or 100\%. Master of Education major in THE total number of graduates was 24 students and total number of traced employed was 24 or $100 \%$. Master of Education major in Science Tech. total number of graduates was 16 students and total number of traced employed was 16 or $100 \%$. Master of Education major in PE total number of graduate was 1 student and total number of traced employed was 1 or $100 \%$. Master of Education major in Mathematics total number of graduates was 15 students and total number of traced employed was 15 or $100 \%$. Master of Education major in GC total number of graduate was 1 student and total number of traced employed was 1 or 100\%. Master of Education major in English total number of graduates was 13 students and total number of traced employed was 13 or $100 \%$. Master of Education major in Educational Management total number of graduates was 20 students and total number of traced employed was 20 or $100 \%$. Doctor of Education total number of graduates was 12 students and total number of traced employed was 12 or $100 \%$.

Table 1. Frequency distribution number of Employed, Unemployed and Not Tracked in College of Teachers Education from batch 2017

1.

2. College of Teacher

Education

3. Employed

6. Total 7. Percentage

8. Total 9. Percentage

10. Tot

al

5. Not Tracked

12. BSIE

Drafting 13.1

14. $100 \%$

Technology

19. BSIE Home Economics

20. 21

21. $80.77 \%$

22. 0

23. 0

17. 0

18. 0

26. BSIE Industrial Arts

$27.5 \quad 28.100 \%$

29. 0

30. 0

31. 0

32. 0

33. BSED Bio Sci

34. 16

35. $80 \%$

36. 0

37. 0

38. 4

39. $20 \%$

40. BSED English

41. 49

42. $87.5 \%$

43. 0

44. 0

45. 7

46. $12.5 \%$

47. BSED Filipino

48. 44

49. $93.62 \%$

50. 0

51. 0

52.3

53. $6.38 \%$ 


\begin{tabular}{|c|c|c|c|c|c|c|}
\hline 54. BSED MAPEH & 55.27 & $56.81 .82 \%$ & 57.0 & 58.0 & 59.6 & $60.18 .18 \%$ \\
\hline 61. BSED Mathematics & 62.38 & $63.80 .85 \%$ & 64.0 & 65.0 & 66.9 & 67. $19.15 \%$ \\
\hline 68. BSED Physci & 69.11 & $70.84 .62 \%$ & 71.0 & 72.0 & 73.2 & 74. $15.38 \%$ \\
\hline 75. BSED Soc Sci & 76.42 & 77. $82.35 \%$ & 78.0 & 79.0 & 80.9 & $81.17 .65 \%$ \\
\hline 82. BSED TLE & 83.23 & $84.100 \%$ & 85.0 & 86.0 & 87.0 & 88.0 \\
\hline $\begin{array}{l}\text { 89. BEED } \\
\text { Education }\end{array}$ & 90.42 & $91.87 .5 \%$ & 92.0 & 93.0 & 94.6 & $95.12 .5 \%$ \\
\hline $\begin{array}{l}\text { 96. BEED Pre-Elem. } \\
\text { Education }\end{array}$ & 97.12 & $98.92 .31 \%$ & 99.0 & 100.0 & 101.1 & $102.12 \%$ \\
\hline 103. BEED Pre-SPED & 104.1 & $105.100 \%$ & 106.0 & 107.0 & 108.0 & 109.0 \\
\hline $\begin{array}{l}\text { 110. Certificate in Teaching } \\
\text { Proficiency }\end{array}$ & 111.8 & $112.100 \%$ & 113.0 & 114.0 & 115.0 & 116.0 \\
\hline 117. MAT English & 118.6 & $119.100 \%$ & 120.0 & 121.0 & 122.0 & 123.0 \\
\hline 124. MAED- THE & 125.24 & $126.100 \%$ & 127.0 & 128.0 & 129.0 & 130.0 \\
\hline 131. MAED- Soc Sci & 132.9 & $133.100 \%$ & 134.0 & 135.0 & 136.0 & 137.0 \\
\hline 138. MAED- Sci Tech & 139. 16 & $140.100 \%$ & 141.0 & 142.0 & 143.0 & 144.0 \\
\hline 145. MAED PE & 146.1 & $147.100 \%$ & 148.0 & 149.0 & 150.0 & 151.0 \\
\hline 152. MAED Math & 153.15 & $154.100 \%$ & 155.0 & 156.0 & 157.0 & 158.0 \\
\hline 159. MAED GC & 160.1 & $161.100 \%$ & 162.0 & 163.0 & 164.0 & 165.0 \\
\hline 166. MAED Filipino & 167.13 & $168.100 \%$ & 169.0 & 170.0 & 171.0 & 172.0 \\
\hline
\end{tabular}


180. MAED

194. TOTAL

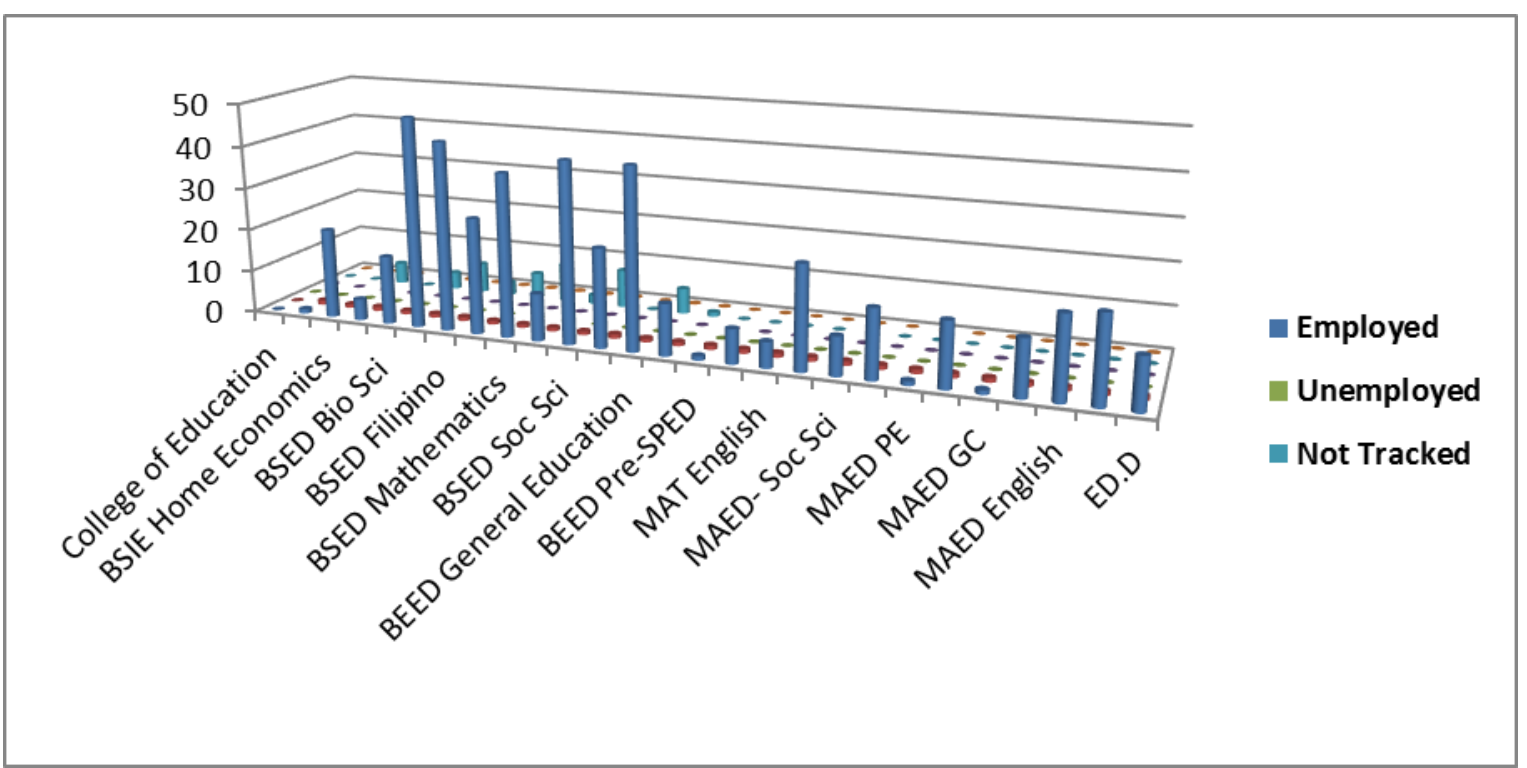

Employment Status of College of Teacher Education from Batch 2017

The figure shows total number of College of Teacher Education Graduates from the year of 2017 was 528 students.

Figure 1. Employment Status of College of Teacher Education from Batch 2017

Frequency distribution number of Employed, Unemployed and Not Tracked in College of Education from batch 2018

Bachelor of Industrial Education major in Home Economics total number of graduates was 1 student and total number of traced employed was 1 or $100 \%$. Bachelor of Secondary Education major in Bio Science total number of graduates was 33 students and total number of traced employed was 28 or $84.85 \%$ and total numbers of not traced was 5 or $15.15 \%$. Bachelor of Secondary Education major in English total number of graduates was 49 students and total number of traced employed was 45 or $91.83 \%$ and total number of not tracked was 5 or $15.15 \%$. Bachelor of Secondary Education major in Filipino total number of graduates was 42 students and total number of traced employed was 42 or $100 \%$. Bachelor of Secondary Education major in MAPEH total number of graduates was 35 students and total number of traced employed was 33 or $94.28 \%$ and total number of not traced was 2 or $5.71 \%$. Bachelor of Secondary Education major in Mathematics 
total number of graduates was 33 students and total number of traced employed was 32 or $92.97 \%$ and total number of not traced was 1 or $3.03 \%$. Bachelor of Secondary Education major in Physical Science total number of graduates was 24 students and total number of traced employed was 22 or $84.62 \%$ and total number of not traced was 2 or $15.38 \%$. Bachelor of Secondary Education major in Social Science total number of graduates was 36 students and total number of traced employed was 36 or $100 \%$. Bachelor of Secondary Education major in TLE total number of graduates was 37 students and total number of traced employed was 37 or 100\%. Bachelor of Elementary Education major in General Education total number of graduates was 41 students and total number of traced employed was 40 or $96.97 \%$ and total number of unemployed was 1 or 3.03\%. Bachelor of Elementary Education major in Pre-Elem. Education total number of graduates was 32 students and total number of traced employed was 32 or 100\%. Bachelor of Elementary Education major in SPED total number of graduates was 13 students and total number of traced employed was 13 or $100 \%$. BTTE major in Civic Technology total number of graduates was 8 students and total number of traced employed was 8 or $100 \%$. BTTE major Garments, Fashion and Design Technology total number of graduates was 19 students and total number of traced employed was 19 or $100 \%$. BS major in English total number of graduate was 1 students and total number of traced employed was 13 or $100 \%$.

Table 2. Frequency distribution number of Employed, Unemployed and Not Tracked in College of Teacher Education from batch 2018

\section{1. \\ 202. College of Teacher \\ 203. Education}

213. BSIE Home Economics

220. BSED Bio Sci

227. BSED English

234. BSED Filipino

241. BSED MAPEH

248. BSED Mathematics

255. BSED Physci

262. BSED Soc Sci

269. BSED TLE

276. BEED General Education
204. Employed

207. To 208. Percentage

tal

214. $1 \quad 215.0$

$221.28 \quad 222.84 .85 \%$

$228.45 \quad 229.91 .83 \%$

$235.42 \quad 236.100 \%$

$242.33 \quad 243.94 .28 \%$

$249.32 \quad 250.96 .97 \%$

$256.22 \quad 257.84 .62 \%$

258. 0

$263.36 \quad 264.100 \%$

$270.37 \quad 271.100 \%$

277. 40

278. $96.97 \%$

al

216. 0

223. 0

230.1

237. 0

265. 0
205. Unemployed

209. Tot 210. Percentage

238. 0

245. 0

252. 0

259. 0

266. 0

272. 0

273. 0
$267.0 \quad 268.0$

274. $0 \quad 275.0$

\section{Not Tracked}

211. T 212. Percentage otal

$218.0 \quad 219.0$

$225.5 \quad 226.15 .15 \%$

$232.3 \quad 233.6 .12 \%$

$239.0 \quad 240.0$

246. $2 \quad 247.5 .71 \%$

$253.1254 .3 .03 \%$

260. 2 261. $15.38 \%$

$281.0 \quad 282.0$ 
283. BEED

Pre-Elem. 284. $32 \quad 285.100 \%$

286. 0

287. 0

$288.0 \quad 289.0$

Education

290. BEED Pre-SPED

$291.13292 .100 \%$

293. 0

294. 0

$295.0 \quad 296.0$

297. BTTE Civic Technology

$298.8 \quad 299.100 \%$

300.0

301.0

$302.0 \quad 303.0$

304. BTTE Food and Service

$306.24 \quad 307.100 \%$

308. 0

309. 0

$310.0 \quad 311.0$

305. Management 4

312. BTTE Garments,

313. Fashion and Design

315. $19316.100 \%$

317.0

318. 0

$319.0 \quad 320.0$

314. Technology

321. BS English

$322.1-323.100 \%$

324. $0 \quad 325.0$

$326.0 \quad 327.0$

328. TOTAL

329. $41330.96 .63 \%$ 3

$331.2 \quad 332.3 .17 \%$

333. 1 334. 6.48\%

3

\section{Employment Status of College of Teacher Education from Batch 2018}

The figure shows total number of College of Teacher Education Graduates from the year of 2018 was 428 students.

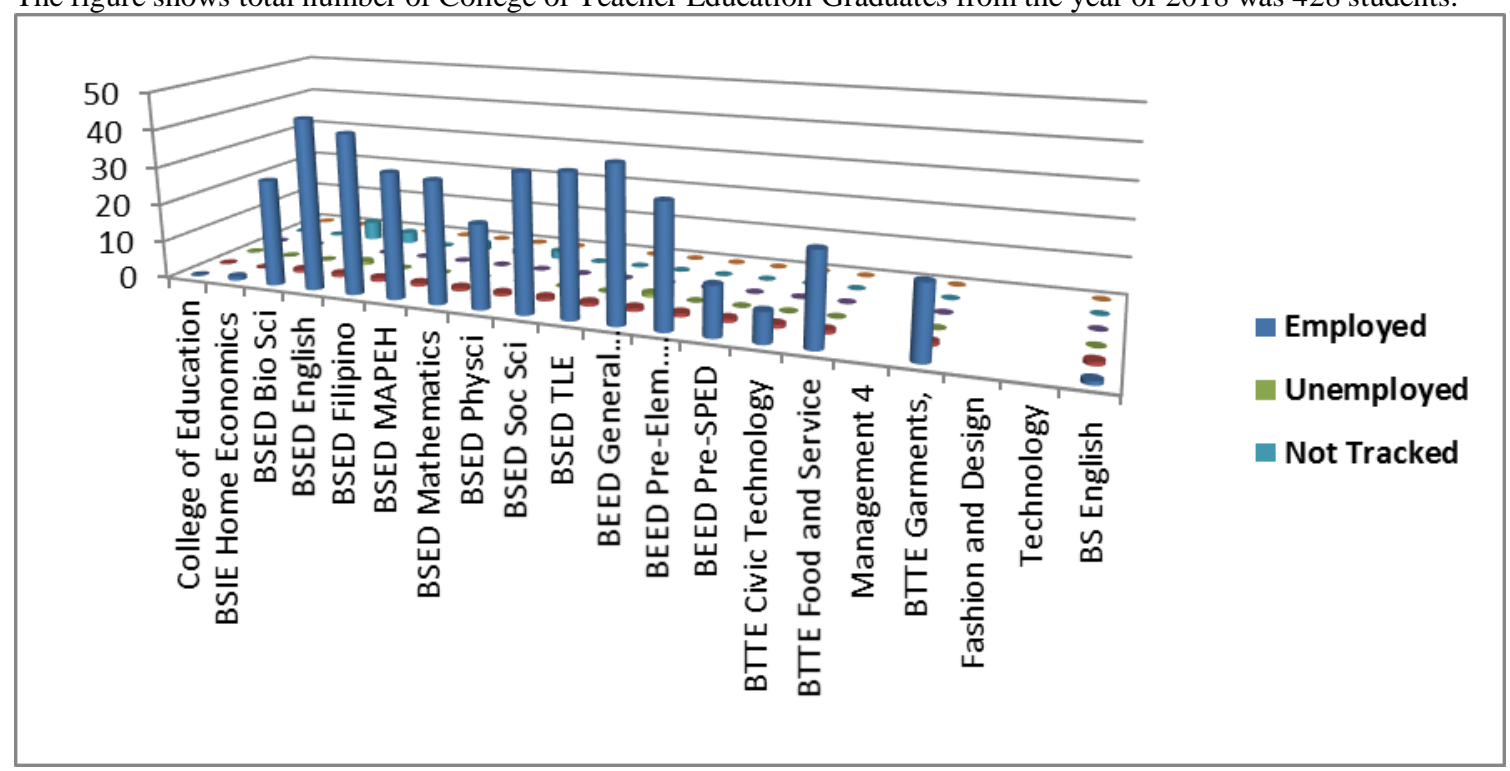

Figure 2. Employment Status of College of Teacher Education from Batch 2018 
Bachelor of Technical Teacher Education major in Garment, Fashion and Design total number of graduates was 17 students and total number of traced employed was 2 or $11.76 \%$ total number of traced unemployed was 1 or $15.88 \%$ and total number of not tracked was 14 or $82.35 \%$. Bachelor of Technical Teacher Education major in Food Service Management total number of graduates was 30 students and total number of traced employed was 1 or $3.33 \%$ total number of traced unemployed was 4 or $13.33 \%$ and total number of not tracked was 25 or $83.75 \%$. Bachelor of Technical Teacher Education major in Electronics total number of graduates was 12 students and total number of traced employed was 1 or $8.33 \%$ and total number of not tracked was 11 or $91.67 \%$. Bachelor of Technical Teacher Education major in Drafting total number of graduates was 8 students and total number of not tracked was 8 or 100\%. Bachelor of Technical Teacher Education major in Civil Technology total number of graduates was 3 students and total number of not tracked was 3 or $100 \%$. Bachelor of Secondary Education major in TLE total number of graduates was 20 students and total number of traced employed was 3 or $15 \%$ total number of traced unemployed 4or $20 \%$ and total numbers of not traced was 13 or $65 \%$. Bachelor of Secondary Education major in Social Science total number of graduates was 42 students and total number of traced employed was 8 or $19.05 \%$ total number of traced unemployed 6 or $14.29 \%$ and total numbers of not traced was 28 or $66.67 \%$. Bachelor of Secondary Education major in Physical Science total number of graduates was 13 students and total number of traced employed was 10 or $76.92 \%$ total number of traced unemployed 3 or $23.08 \%$. Bachelor of Secondary Education major in Mathematics total number of graduates was 30 students and total number of traced employed was 12 or $40 \%$ total number of traced unemployed was 2 or $6.67 \%$ and total number of not traced was 16 or $53.33 \%$. Bachelor of Secondary Education major in MAPEH total number of graduates was 28 students and total number of traced employed was 25 or $89.29 \%$ and total number of not traced was 3 or $10.71 \%$. Bachelor of Secondary Education major in Filipino total number of graduates was 23 students and total number of traced employed was 11 or $47.83 \%$ total number of traced unemployed was 2 or 8.70 and total number of not traced was 10 or $43.48 \%$. Bachelor of Secondary Education major in English total number of graduates was 34 students and total number of traced employed was 10 or $29.41 \%$ and total number of not traced was 24 or $80 \%$. Bachelor of Secondary Education major in Bio Science total number of graduates was 18 students total number of traced unemployed 3 or $16.67 \%$ and total number of traced employed was 8 or $44.44 \%$. Bachelor of Elementary Education major in SPED total number of graduate was 1 student and total number of traced unemployed was 1 or $100 \%$. Bachelor of Elementary Education major in Pre-Elem. Education total number of graduates was 7 students and total number of traced unemployed was 1 or $14.29 \%$ and total number of not traced was 6 or $85.71 \%$. Bachelor of Elementary Education major in General Elementary total number of graduates was 34 students total number of traced employed was 7 or $20.59 \%$ total number of traced unemployed was 3 or $12.5 \%$ and total number of not tracked was 24 or $70.59 \%$.

Table 3. Frequency distribution number of Employed, Unemployed and Not Tracked in College of Education from batch 2019

335.

336. College of Teacher

Education

346. BBTE- GFD

353. BTTE- FSM

354.

337. Employed

338. Unemployed

339. Not Tracked

Education

360. BTTE- Electronics

340. To 341. Percentage tal

$347.2 \quad 348.11 .76 \%$

355. $3.33 \%$

362. $8.33 \%$

367. BTTE- Drafting
$368.0 \quad 369.0$
363. 0

364. 0

342. Tot
al

349. 1

356.4

357. $13.33 \%$

$370.0 \quad 371.0$
365.11

366. $91.67 \%$

358. 25

359. $83.33 \%$

344. To 345. Percentage tal

351.14

352. $82.35 \%$

$373.100 \%$ 


\begin{tabular}{|c|c|c|c|c|c|c|}
\hline 374. BTTE- Civil Technology & 375.0 & 376.0 & 377.0 & 378.0 & 379.3 & $380.100 \%$ \\
\hline 381. BSED TLE & 382.3 & $383.15 \%$ & 384.4 & $385.20 \%$ & 386.13 & $387.65 \%$ \\
\hline 388. BSED Physci & 389.10 & $390.76 .92 \%$ & 391.3 & $392.23 .08 \%$ & 393.0 & 394.0 \\
\hline 395. BSED Soc Sci & 396.8 & $397.19 .05 \%$ & 398.6 & $399.14 .29 \%$ & 400.28 & $401.66 .67 \%$ \\
\hline 402. BSED Math & 403.12 & $404.40 \%$ & 405.2 & $406.6 .67 \%$ & 407.16 & $408.53 .33 \%$ \\
\hline 409. BEED MAPEH & 410.25 & $411.89 .29 \%$ & 412. 0 & 413.0 & 414.3 & $415.10 .71 \%$ \\
\hline 416. BSED Filipino & 417.11 & $418.47 .83 \%$ & 419.2 & $420.8 .70 \%$ & 421.10 & $422.43 .48 \%$ \\
\hline 423. BSED English & 424. 10 & $425.29 .41 \%$ & 426.0 & 427.0 & 428.24 & $429.80 \%$ \\
\hline 430. BSED Bio Sci & 431.7 & $432.38 .89 \%$ & 433.3 & 434. $16.67 \%$ & 435.8 & $436.44 .44 \%$ \\
\hline 437. BEED SPED & 438.0 & 439. 0 & 440.1 & $441.100 \%$ & 442. 0 & 443.0 \\
\hline 444. BEED Pre Elem & 445.0 & 446.0 & 447.1 & $448.14 .29 \%$ & 449.6 & $450.85 .71 \%$ \\
\hline 451. BEED Gen Elem & 452.7 & $453.20 .59 \%$ & 454.3 & $455.12 .5 \%$ & 456.24 & $457.70 .59 \%$ \\
\hline 458. TOTAL & 459.97 & $460.25 .03 \%$ & 461.30 & $462.14 .71 \%$ & $\begin{array}{l}463.19 \\
3\end{array}$ & 464. $61.08 \%$ \\
\hline
\end{tabular}

\section{Employment Status of College of Teacher Education from Batch 2019}

The figure shows total number of College of Teacher Education Graduates from the year of 2019 was 320 students. 


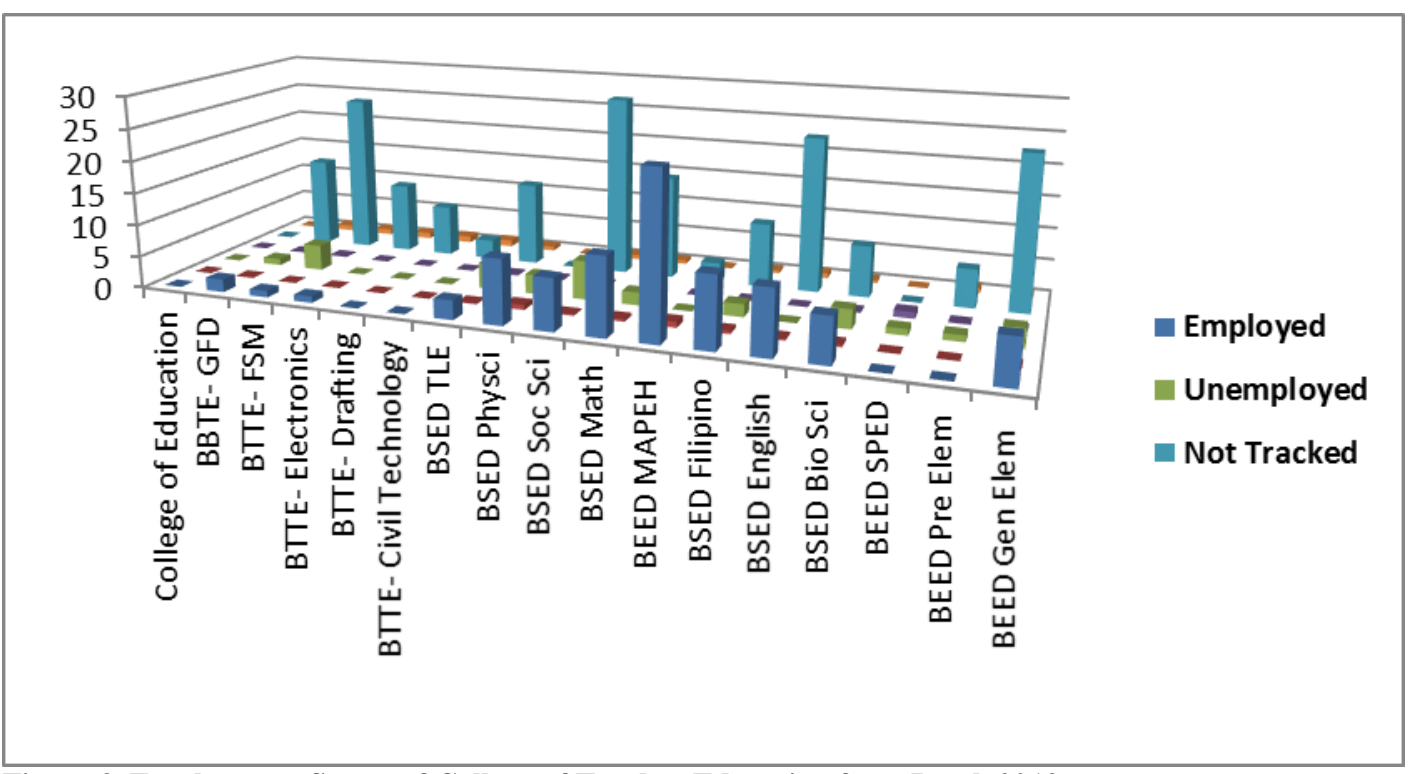

Figure 3. Employment Status of College of Teacher Education from Batch 2019

Summary of Employment Status in College of Teacher Education from Batch 2017, 2018

And 2019

Employment Status in College of Teacher Education the year of 2017 total number of graduates was 528 students total number of traced employed was 476 or $94 \%$ and total number of not tracked was 52 or $6 \%$. College of Teacher Education the year of 2018 total number of graduates was 428 students total number of traced employed 413 or $86.63 \%$ total number of traced unemployed was 2 or $3.17 \%$ and total number not tracked was 13 or $6.48 \%$. College of Teacher Education the year of 2019 total number of graduates was 320 students total number traced employed was 97 or $25.03 \%$ total number of traced unemployed was 30 or $14.71 \%$ and total number of not tracked was 193 or $61.08 \%$.

Table 7. Summary of Employment Status in College of Teacher Education from Batch 2017, 2018 and 2019

\begin{tabular}{lllllll}
$\begin{array}{l}\text { 465. College of } \\
\text { Teacher Education }\end{array}$ & \multicolumn{2}{l}{ 466. Employed } & \multicolumn{2}{l}{ 467. Unemployed } & \multicolumn{2}{c}{ 468. Not Tracked } \\
& 469. Total & 470. Percentage & 471. Total & 472. Percentage & 473. Total & 474. Percentage \\
475. 2017 & 476.476 & $477.94 \%$ & 478.0 & 479.0 & 480.52 & $481.6 \%$ \\
482.2018 & 483.413 & $484.96 .63 \%$ & 485.2 & $486.3 .17 \%$ & 487.13 & $488.6 .48 \%$ \\
489.2019 & 490.97 & $491.25 .03 \%$ & 492.30 & $493.14 .71 \%$ & 494.193 & $495.61 .08 \%$
\end{tabular}

Summary of Employment Status in College of Teacher Education from Batch 2017, 2018 and 2019

The figure shows total number of Employment Status in College of Teacher Education Graduates from the year of 2017, 2018 and 2019 


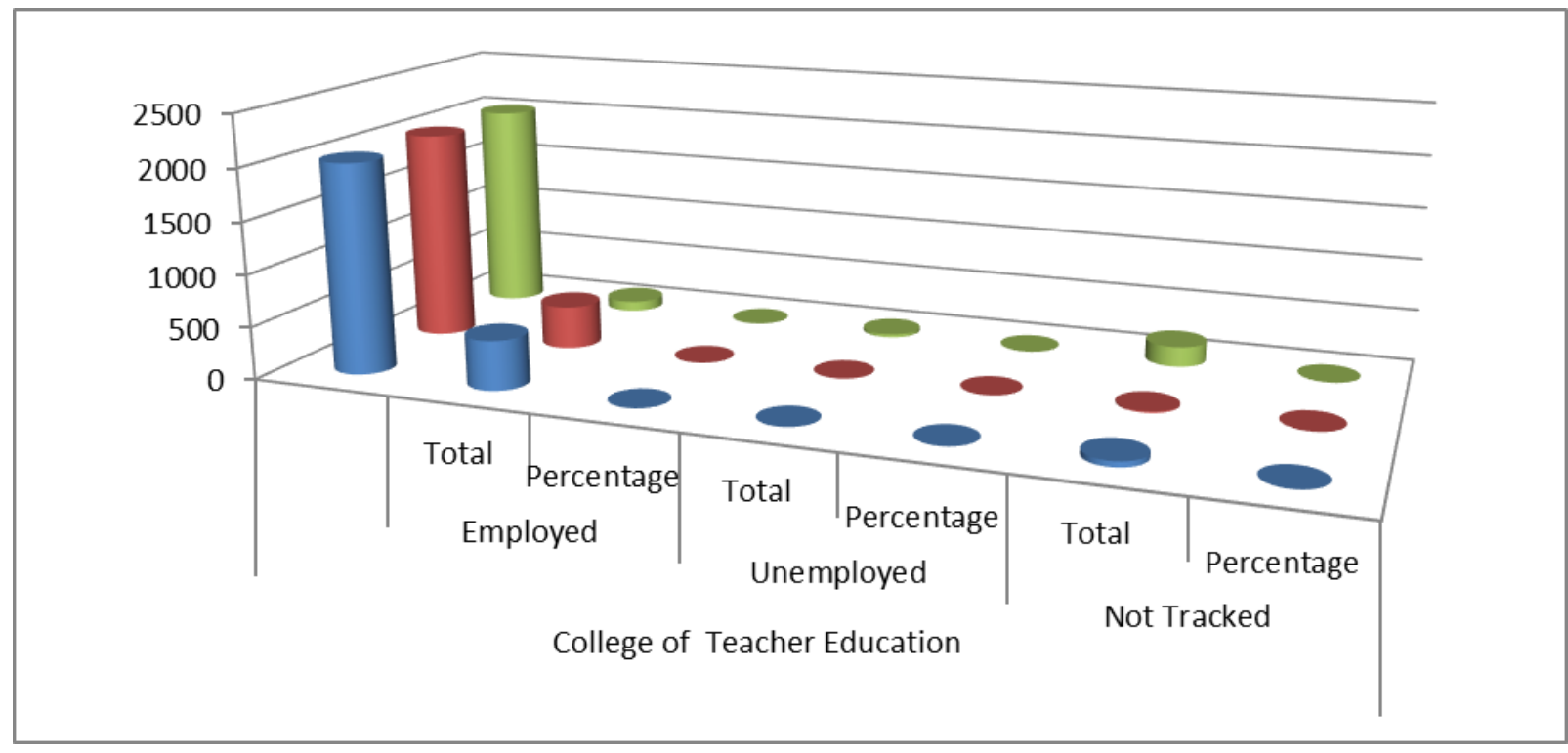

Figure 4. Summary of Employment Status in College of Teacher Education from Batch 2017, 2018 and 2019

The alumni who are serving the different schools in all levels (tertiary, secondary and elementary) were requested to fill out the CTE Graduate Tracer Form through their respective heads. Alumni who are non-teaching and serving private and public agencies were personally asked to fill out the questionnaire. To help us trace the graduates, the students from the college were requested to reach their alumni relatives and friends. Likewise, the social media, particularly through FB and emails, were used to trace and communicate with the alumni.

The Employment Status of College of Teacher Education Graduates from batch 2017, 2018 and 2019, total number of graduates from A.Y 2016-2017 was 528 students, total number of graduates from A.Y 2017-2018 was 428 students and total number of graduates from A.Y 2018-2019 was 320 students, their response will serve as basis for an enhancement teacher training program and revision/modification/improvement of the existing program of the college of teacher education.

The Employment Status Of College Of Teacher Education Graduates From Batch 2017, 2018 And 2019, The Response Will Serve As Basis For An Enhancement Teacher Training Program And Revision/Modification/Improvement Of The Existing Program Of The College Of Teacher Education.

Table 4. Current Employment Status in terms of Employed, Presently not employed but seeking for work, Reason (s) for staying on the job, Reasons for changing job and Never employed

\begin{tabular}{|c|c|c|c|c|c|c|}
\hline $\begin{array}{l}\text { 496. Current Employment } \\
\text { Status in terms of } \\
\text { Emploved }\end{array}$ & $\begin{array}{l}\text { 497. Y } \\
\text { ES }\end{array}$ & $\begin{array}{l}\text { 498. Percenta } \\
\text { ge }\end{array}$ & $\begin{array}{l}\text { 499. N } \\
\text { O }\end{array}$ & 500. Percentage & $\begin{array}{l}\text { 501. Mayb } \\
\text { e }\end{array}$ & $\begin{array}{l}\text { 502. Percentag } \\
\text { e }\end{array}$ \\
\hline - Regular or permanent & $\begin{array}{l}503 . \\
504.33 \\
5\end{array}$ & $\begin{array}{l}505 . \\
506.38 .09 \%\end{array}$ & $\begin{array}{l}507 . \\
508.2 \\
90\end{array}$ & $\begin{array}{l}509 . \\
510.11 \%\end{array}$ & $\begin{array}{l}511 . \\
512.0\end{array}$ & $\begin{array}{l}513 . \\
514.0\end{array}$ \\
\hline $\begin{array}{l}\text { - Contractual/project- } \\
\text { based/Job Order }\end{array}$ & $\begin{array}{l}515.40 \\
1\end{array}$ & $516.31 .82 \%$ & $\begin{array}{l}517 . \\
518.1 \\
45\end{array}$ & $\begin{array}{l}519 . \\
520.8 .69 \% \\
521 .\end{array}$ & $\begin{array}{l}522 . \\
523.0\end{array}$ & $\begin{array}{l}524 . \\
525.0\end{array}$ \\
\hline - Temporary & 526.87 & $527.6 \%$ & $\begin{array}{l}528.1 \\
8\end{array}$ & $529.4 .4 \%$ & $\begin{array}{l}530 . \\
531.0\end{array}$ & $\begin{array}{l}532 . \\
533.0\end{array}$ \\
\hline
\end{tabular}




$\begin{array}{cc}\bullet & \text { Total } \\ \text { Range } & \text { Description } \\ 1 & \text { YES } \\ 2 & \text { NO } \\ 3 & \text { MAYBE }\end{array}$

534. $75.91 \%$

Verbal Interpretation

Agree

Disagree

Neutral
535. $24.09 \%$

536.0

Table 5. Current Employment Status in terms of presently not employed but seeking for work

537. Current Employment 538 .

541.

544. 547 .

550.

Status in terms of Presently 539.

542.

545.548.

551.

for work

540. $Y$ 543. Percenta

ES ge

556.558

- Advance or further

$557.50 \quad 559.10 .9 \%$

O

560.562

study

- Family concern and $570 . \quad 572$. 568 . decided not to find a job $\quad 571.14 \quad 573.0 .21 \%$

569.

- Health-related reasons $\quad 583.8 \quad 584.0 .16 \%$

- Lack of work 591.86 592.52.14\% experience

$597.55 \quad 598.12 .06 \%$

- No job opportunity

$603.20 \quad 604.1 .02 \%$

- Did not look for a job

610. $75.68 \%$

609. Total

Range Description

$\begin{array}{ll}1 & \text { YES } \\ 2 & \text { NO } \\ 3 & \text { MAYBE }\end{array}$

Verbal Interpretation

Agree

Disagree

Neutral

$561.2563 .1 .04 \%$

3

$574 . \quad 576$.

$575.2577 .1 .24 \%$

$8 \quad 578$

585. $1 \quad 586.0 .21 \%$

4

$593.4 \quad 594.7 .26 \%$

$599.5600 .12 .11 \%$

$605.2 \quad 606.1 .12 \%$

4

611. $22.98 \%$

e

564.

565.8

Table 6. Current Employment Status in terms of Reason (s) for staying on the job

613. Current Employment Status in terms of Reason

(s) for staying on the job

- $\quad$ Salaries and benefits program of study

- Family Influence

- Peer and relationships

- Career challenge work

Related to special skill

- Proximity to residence

\begin{tabular}{llll}
$\mathbf{6 1 4 .}$ & $\mathbf{6 1 7 .}$ & $\mathbf{6 2 0 .}$ & $\mathbf{6 2 3 .}$ \\
$\mathbf{6 1 5 .}$ & $\mathbf{6 1 8 .}$ & $\mathbf{6 2 1 .}$ & $\mathbf{6 2 4 .}$ \\
$\mathbf{6 1 6 .} \mathbf{Y}$ & $\mathbf{6 1 9 .}$ Percenta & $\mathbf{6 2 2 .} \mathbf{N}$ & $\mathbf{6 2 5 .}$ Percentage \\
$\mathbf{E S}$ & ge & $\mathbf{O}$ & \\
632. & 634. & 636. & 638. \\
633.48 & $635.38 \%$ & 637.0 & 639.0 \\
5 & & & \\
644. & 646. & 648. & 650. \\
645.16 & $647.13 .09 \%$ & 649.1 & $651.0 .86 \%$ \\
7 & & 1 & \\
656.34 & $657.2 .66 \%$ & 658.1 & $659.0 .86 \%$ \\
664.7 & $665.0 .55 \%$ & 666.4 & $667.0 .31 \%$ \\
670.95 & $671.0 .7 \%$ & 672.5 & $673.0 .39 \%$ \\
676.32 & $677.2 .51 \%$ & 678.4 & $679.3 .53 \%$ \\
682.25 & $683.1 .96 \%$ & 684.2 & $685.1 .80 \%$ \\
& & 3 & \\
\hline
\end{tabular}

614.

552. Mayb

$579 . \quad 581$

580. $11 \quad 582.0 .18 \%$

$588 . \quad 590$.

$595.5 \quad 596.0 .09 \%$

$601.6 \quad 602.0 .12 \%$

$607.0 \quad 608.0$

612. $0.53 \%$

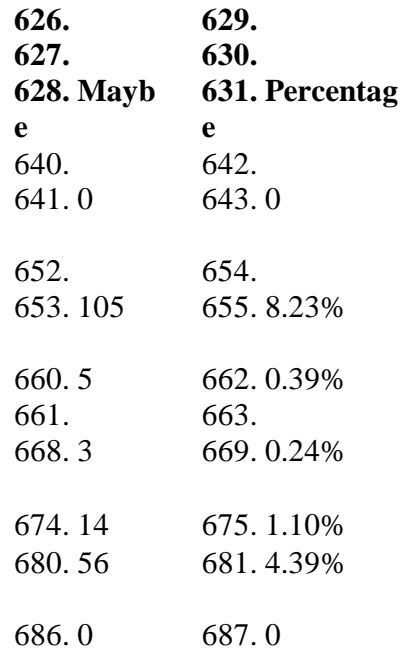

553.

555. Percentag

566.

$567.0 .14 \%$ 
- For experience

694. Total

Range Description

1 YES

2 NO

3 MAYBE
$688.10 \quad 689.7 .83 \%$

0

695. 67.3\%

$690.1 \quad 691.1 .10 \%$

696. $8.85 \%$

Verbal Interpretation

Agree

Disagree

Neutral
692.35

$693.2 .74 \%$

697. 17.09\%

Table 7. Current Employment Status in terms of Reasons for changing job

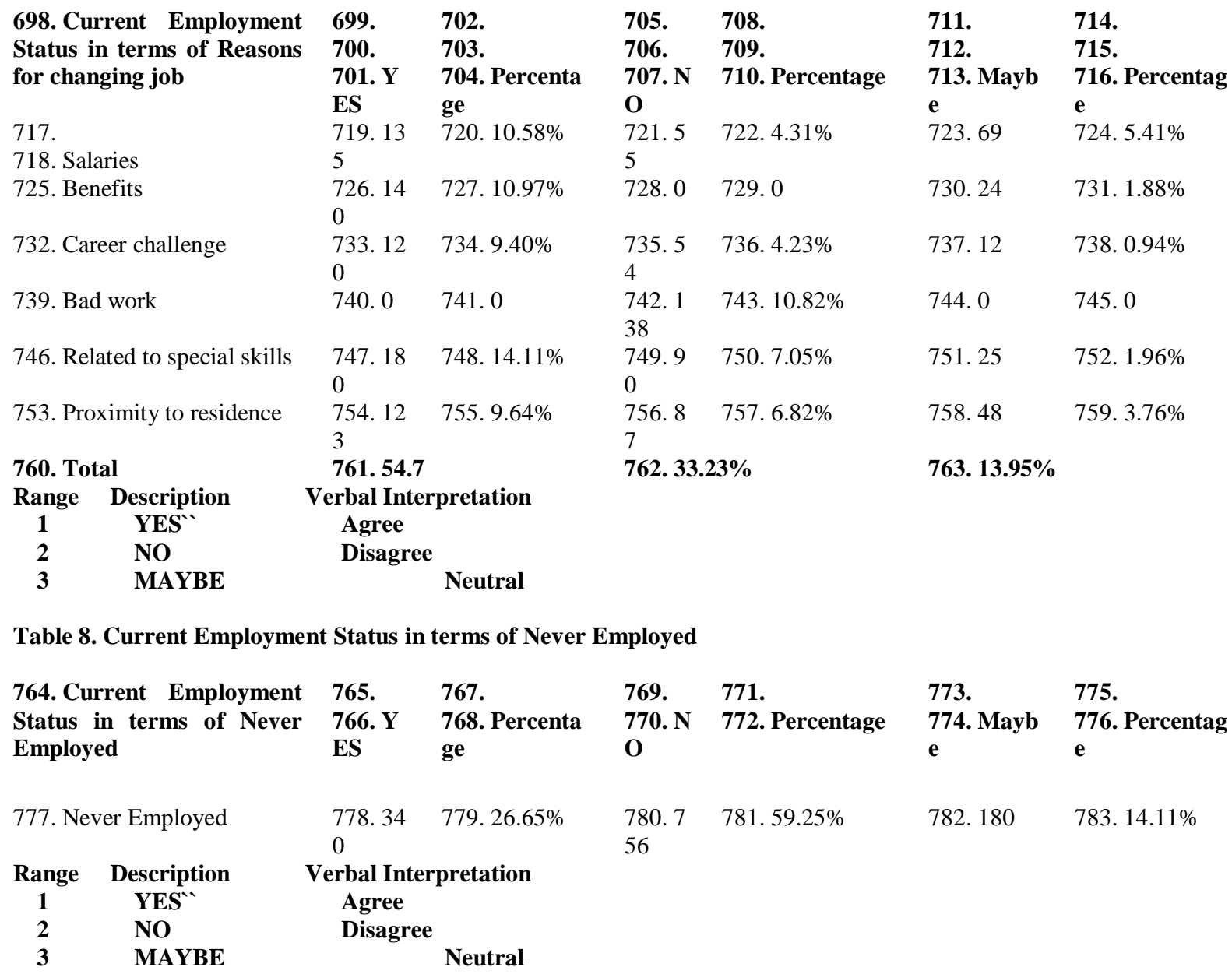

Jobseekers Experiences in terms of (a) what strategies you've made in finding job? (b) What are the difficulties you experience in looking/searching for a job? (c) After you were able to find a vacancy, what are the possible reasons why you did not get the job? 
Table 9. Jobseekers Experiences in terms of (a) what strategies you've made in finding job

(a) What strategies
you've made in
finding job?

- Application to vacant position

- Personal connections/contact

- $\quad$ Through parents/relatives help

- The employer offered me vacancy

- I am working for same employer as I did during my studies

- Contacting employers without knowing about vacancy

- Contacts established with

- employees through work experience in the course of study/OJT

- My own advertisement

- On line (face book, job sites

- Job fair

$\begin{array}{cc}\bullet & \text { Total } \\ \text { Range } & \text { Description } \\ 1 & \text { YES } \\ \mathbf{2} & \text { NO } \\ \mathbf{3} & \text { MAYBE }\end{array}$

$\begin{array}{ll}\text { 784. Y } & \text { 785. Percenta } \\ \text { ES } & \text { ge }\end{array}$

$790.25791 .1 .96 \%$ 792.

$801.13 \quad 803.1 .09 \%$ $802 . \quad 804$

$814 . \quad 816$

$815.17 \quad 817.1 .33 \%$

826. $29 \quad 827.2 .27 \%$

832. 834

833. $19 \quad 835.1 .49 \%$

$844 . \quad 846$

$845.28 \quad 847.2 .19 \%$

$856 . \quad 859$.

$857 . \quad 860$

$837.2 \quad 839.1 .80 \%$

$848 . \quad 850$.

862. 865 .

\begin{tabular}{ll}
874.9 & $875.0 .71 \%$ \\
880.26 & $881.20 .38 \%$ \\
0 & \\
886.16 & $887.12 .93 \%$ \\
5 & \\
892. 51.98\% \\
Verbal Interpretation \\
Agree \\
Disagree \\
\multicolumn{2}{c}{ Neutral }
\end{tabular}

786. N 787. Percentage

O

793. 2 795. $2.19 \%$

8796.

794.

805.3807.

$7 \quad 808.2 .90 \%$

806.809 .

$818 . \quad 820$.

$819.3 \quad 821.3 .06 \%$

9

$828.2 \quad 829.2 .12 \%$

7

836. $\quad 838$

3

$849.4 \quad 851.3 .84 \%$

9

$863 . \quad 866$

$864.4 \quad 867.3 .68 \%$

7

788. Mayb 789. Percentag

e e

797. $5 \quad 799.0 .39 \%$

798.800 .

810.18 812.1.41\%

$811 . \quad 813$

$822 . \quad 824$.

823. $15 \quad 825.1 .18 \%$

$830.8 \quad 831.0 .63 \%$

$840 . \quad 842$.

$841.12 \quad 843.0 .94 \%$

$852 . \quad 854$.

$853.9 \quad 855.0 .71 \%$

$868 . \quad 871$.

$869 . \quad 872$

870. $11 \quad 873.0 .86 \%$

$\begin{array}{llll}876.3 & 877.2 .66 \% & 878.17 & 879.1 .33 \% \\ 4 & & & \\ 882.1 & 883.9 .01 \% & 884.55 & 885.4 .31 \% \\ 15 & & & \\ 888.9 & 889.7 .05 \% & 890.40 & 891.3 .13 \%\end{array}$

$\begin{array}{ll}0 & \text { 893. } 38.31 \%\end{array}$

Table 10. Jobseekers Experiences in terms of $(b)$ what are the difficulties you experience in looking/searching for a job?

- (b) What are the 895 . 898 difficulties you 896. 899. experience in 897. Y 900. Percenta looking/searching for a job?

- No difficulties/not applicable ES ge

914. $1.96 \%$ 915.

- Limited information on 924.58 925.4.55\% available jobs
901.904.

902. 905.

903. N 906. Percentage

$\mathbf{O}$

916. $1918.1 .18 \%$

5919

917.

926. 1 927. $1.18 \%$
907.9910.

908.9911.

909. Mayb 912. Percentag

e

920. $12922.0 .94 \%$

921.923.

928. $27 \quad 929.2 .12 \%$ 
- Considered too young 930.76 931.5.96\% by employers

- Due to family $936.85937 .6 .66 \%$ responsibilities

- Insufficient work $942.40 \quad 943.3 .13 \%$ experience

- Lack necessary skills or $948.56 \quad 949.4 .39 \%$ education

$\bullet$

- No vacancies

- No vacancies in line of $960.11 \quad 961.8 .62 \%$ field of study/course

- Financial constraint 0

- Health concerns/Disability

- Too far travel/transport

- Total

Range Description

1 YES

2 NO

3 MAYBE

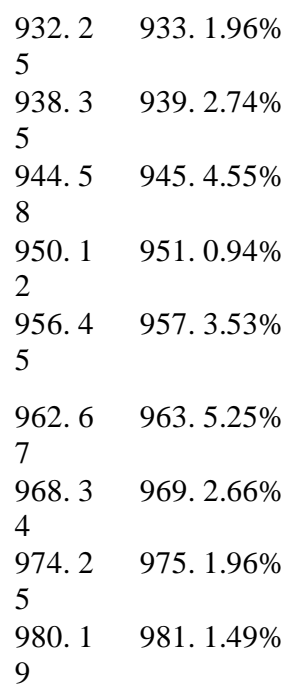

985. $27.44 \%$

$\begin{array}{ll}934.21 & 935.1 .65 \% \\ 940.9 & 941.0 .71 \% \\ 946.21 & 947.1 .65 \% \\ 952.14 & 953.1 .10 \% \\ 958.11 & 959.0 .86 \% \\ 964.45 & 965.3 .52 \% \\ 970.15 & 971.1 .18 \% \\ 976.5 & 977.0 .39 \% \\ 982.19 & 983.1 .49 \%\end{array}$

986. $16.61 \%$

Table 11. Jobseekers Experiences in terms of () After you were able to find a vacancy, what are the possible reasons why you did not get the job?

- (c) After you were able to find a vacancy, what are the possible reasons why you did not get the job?

- No difficulties/not applicable

- No feedback from the employer

- Insufficient

- /irrelevant work $1018.3 \quad 1020.2 .51 \%$ experience competency

- $\quad$ Failed medical exams

$\begin{array}{ll}987 . & 990 . \\ 988 . & 991 . \\ \text { 989. Y } & 992 . \text { Percenta } \\ \text { ES } & \text { ge }\end{array}$

1005.1 1006. $8.23 \%$ 05

$1011.9 \quad 1012.7 .45 \%$ 5

1017. 2

1029. 1 1030. $0.86 \%$

Unsuitable working hours $1035.5 \quad 1036.4 .31 \%$ 5

- Financial constraint in processing documentary requirements

- Unfavourable salary and $1047.5 \quad 1048.4 .39 \%$ benefits

- Did not pass the 1053.1 1054.1.41\% employment
993. 996

994. 997.

995. N 998. Percentage

$\mathbf{0}$

1007. 1 1008. $1.02 \%$ 3

1013. 3 1014. $2.74 \%$

5

1021. 1023.

1022. 1 1024. $1.41 \%$

8

$1031.4 \quad 1032.3 .53 \%$

5

1037. 1 1038. $1.33 \%$

7

1043. 1 1044. $1.49 \%$

9

1049.3 1050. $2.66 \%$

1055. 1 1056. $1.18 \%$ 5
$999 . \quad 1002$

$1000 . \quad 1003$.

1001. May 1004. Percenta

be ge

1009. $24 \quad 1010.1 .88 \%$

1015. $16 \quad 1016.1 .25 \%$

1025.

1026. 9 1028. $0.71 \%$

1033. $4 \quad 1034.0 .31 \%$

1039. $15 \quad 1040.1 .18 \%$

1045. $22 \quad$ 1046. $1.72 \%$

1051. $26 \quad$ 1052. $2.04 \%$

1057. $27 \quad 1058.2 .12 \%$ 
examination

- Did not pass the 1059.3 1060.2.51\% interview 2

- $\quad$ Limited opportunity/

career $1065.7 \quad 1066.6 .11 \%$

- Progress

- In convenient job field 1071.2 1072. 1.96\% assignment

- Self-expression not 107 considered by employer 8

- Total

Range Description

1 YES “

2 NO

3 MAYBE 8

5 1077. $3 \quad 1078.2 .98 \%$

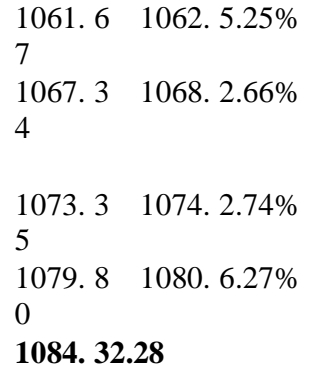

\section{Neutral}

\author{
1063. 29 \\ 1064. $2.27 \%$ \\ 1069. $45 \quad 1070.3 .53 \%$ \\ 1075. $15 \quad 1076.1 .18 \%$ \\ 1081. $11 \quad 1082.0 .86 \%$
}

1085. $19.05 \%$

Table 12. Enhancement of Teacher Training Program

- Enhancement of Teacher Training Program

- Application to vacant position

- Personal connections/contact

- Through parents/relatives help

- The employer offered me vacancy

- I am working for same employer as I did during my studies

- Contacting employers without knowing about vacancy

- Contacts established with

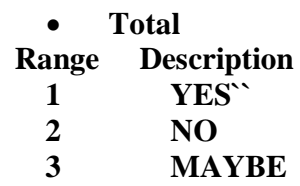

1092. 1095.

1093.1096. 1094. N 1097. Percentage

O 1088. Y 1091. Percent ES age 1104. 5 1105. $4.31 \%$ 5 1110. $1 \quad 1111.13 .79 \%$ 76

1116. 8 1117. $6.97 \%$ 9

$1122.6 \quad 1123.5 .41 \%$ 9

$1128 . \quad 1130$.

$1129.3 \quad 1131.2 .74 \%$ 5

$1140 . \quad 1142$.

$1141.6 \quad 1143.5 .41 \%$ 9

1152. 1154 .

$1153.7 \quad 1155.6 .19 \%$ 9

1164. $44.82 \%$

Verbal Interpretation

Agree

Disagree

Neutral
1106.3 1107. $2.66 \%$

4

1112.4 1113. $3.53 \%$ 5

$1118.91119 .7 .05 \%$

0

1124. $11125.13 .17 \%$

68

1132. 1134.

1133.1 1135. $10.11 \%$ 29

$1144 . \quad 1146$.

1145.1 1147. $10.19 \%$ 30

$1156 . \quad 1158$.

1157. 4 1159. $3.53 \%$

5

1165. 50.24\%
1098.

$1099 . \quad 1102$

1100. May 1103. Percenta

be ge

1108. $6 \quad 1109.0 .47 \%$

1114. $14 \quad 1115.1 .10 \%$

$1120.15 \quad 1121.1 .18 \%$

1126. $13 \quad 1127.1 .02 \%$

1136.

1137. 7 1139. $0.55 \%$

1148.

1149. $5 \quad 1151.0 .39 \%$

1160.

$1161.3 \quad 1163.0 .24 \%$

1166. $4.95 \%$

The data were collated, tabulated and analysed involving frequency and percentage distributions.

\section{Conclusions}

Based from the findings of the study, several conclusions are drawn.

The college has provided quality preparation among the graduates as reflected in a very high degree of the rate of 
employment. Its curriculum is relevant and rich which allow the graduates to have jobbed even right after graduation. Out of the traced graduates, only a few are underemployed and a very minimal number are unemployed.

Generally, the graduates are employed in a teaching job where they are being trained for; only a few are underemployed. They are employed based on the level of learners they are prepared for. A few BSEd graduates teach in the elementary and very minimal number of BEEd graduates teach in the secondary and tertiary level. Only a few are underemployed.

\section{Recommendations:}

The College must continue to provide the best learning experiences and training among the students to be able to maintain a high level of employment especially in the public schools and to be able to provide the same to the students or learners who will also be under their care. It must continue to provide a holistic development among the learners so that they will be ready to face the demands and challenges of the times whether they become employed in teaching or underemployed.

The Alumni Affairs Office in particular, and the College in general, must continue the tracing of graduates and find better strategies to trace them so that the basis for rate of employment will not be the traced graduates but all the graduates it has produced.

A more extensive research to include other factors on employability and employment profile like first jobs, number months or years to wait for employment after graduation must be done.

\section{REFERENCES:}

Aguila, G.M., De Castro E., et.al. (2016). Employability of Computer Engineering Graduates form 2013 to 2015 in one Private Higher Education Institution in the Philippines. Article PDF.

Anayoc, Roy. (2014). A Tracer Study on the Graduates of Colege of Arts and Sciences, University of Southeastern Philippines from School Year 208-20009-to 2012-2013.

Research Study.

Badiru, E.O. and Wahome M. (2016). Conducting Graduate Tracer Studies for Quality

Assurance in East African Universities: A Focus on Graduate Student Voices and

Quality Culture.

Balingbing, A.B., (2014). Tracer Study of BS Information Technology (BSIT) Gradutes of Camarines Sur Polytechnic Colleges, Nabua, Camarines Sur from 2004 to 2010. Research Study published Asia Pacific Journal of Multidisciplinary Research. Volume 2, No 4, (2014).

Boholano, H.B. (2012). Employability of Teacher Education Graduates of an Asian Public University. Journal. Philippine Association of Institutions for Research Inc. Volume

9, No 1 (2012)

Dela Pena, Tancino N., and Lopez J.E. (2016). Employability of the Bachelor of Science in Industrial Technology Graduates of Naval State University-Main Campus, Naval Biliran Philippines. International Journal of Engineering Research and Development

Volume 12, Issue 6, June 2016.

Department of Education (2016). Briones: More Science, Math Teachers Needed. Article. Retrieved from http://www.deped.gov.ph/press-releases/briones-more-science-math-teachers-needed

Dungo, Fehl. (2017). How to become a Police Officer in the Philippines-PNP Requirements.Article. Philpad. Retrieved on February 22, 2017, https://philpad.com/how-to-become-a-police-officer-in-the-philippines-pnp-requirements

Fronda, F. and Villanueva, FC. (2015). Tracer Study of Employment of BSHRM Graduates of The La Consolacion University Philippines from 2011-2013. Research Article. 
Journal of Social Sciences and Humanities Research. Open Access Scientific

Habalo, R. O. (2016). Asian Intellect for Academic Organization and Development, Inc. Books of Abstract. Volume 3 , April 2016.Publisher Volume 1 Issue No 22015

Labaria, Jergen Gel. (2016). Job Satisfaction and Employability of Graduates of Western Philippines University-Quezon Campus. International Conference Research in Social Sciences, Humanities and Education. May 20-21, 2016. Cebu, Philippines.

Lantz, C. (2011) Psychology Student Employability Guide: From University to Career. York:HigherEducationAcademy.Availablefrom:http://www.heacademy.ac.uk/assets/documents/subjects/psychology/Empl oyability_Guide.pdf [accessed 26 April 2013].

Learn.org. (2017). What Are Entry- Level Jobs for Graduates with Biology Majors?.

Retrievedfromlearn.org/articles/What_are_EntryLevel_Jobs_for_Graduates_with_Biology_Majors.html

Lopena, Gina T. (2012). Employability of University of Bohol, BS Psychology Graduates. Abstract. Peer Reviewed Journal Academe, University of Bohol, Graduate School and Studies. Vol 1, No 1 (2012).

Loquias, R. T. (2015). Employability of the Bachelor of Science in Electronics Engineering Graduates of Camarines Sur Polytechnic Colleges. Research Study, Asia Pacific Journal of Multidisciplinary Research Vo. 3 No. 4 November 2015.

Obando, J. and Shisanya, C. (2013). Institutionalizing Tracer Studies in Higher Education Institutions in Africa: The Experience of Kenyatta University. Research Paper. JOINT UNITRACE-IUCEA Conference February 12th, 2013, Safari Park Hotel, Nairobi.

Ocampo, M.B. et.al. (2012). Culture of Entrepreneurship versus Employment. Research Paper. 2012 Fifth TaiwanPhilippines Academic Conference: Digital Humanities and Cultural Studies.

Orejana A., and Resureccion P., (2010). Tracer Study on the Graduates of the BSBA Program: AN Input to Curricular Development. E-Journals.

Phalen, Lisa. (2012). The 50 Best Jobs for Psychologists. Careers in Psychology.

Article. Retrieved from http://careersinpsychology.org/50-best-jobs-psychologists/

Reddy, P. et. al. (2014). Employability in Psychology: a guide for departments. The Higher Education Academy. Employability-guide-final.pdf.

Yaun, M. and Paronda, CH., (2015). Employment and Academic Competencies among Information Technology Graduates: A Tracer Study. Research Study published Philippine Association of Institutions for Research Inc. Volume 6, No 1 (2015)

Yorke,M. \& Knight P. (2003). The undergraduate curriculum and employability. LTSN. Retrieved February 21, 2017, from http.www. 1tsn. acuuk/generic center

Yorke, Mantz. (2004). Employability in Higher Education: what is-what is not; Higher Education Academy ESECT

2001. The Handbook of Research for Educational Communications Technology. The Association for Educational Communications and Technology. Updated August 3, 2001. 2016). BS in Electrical Engineering in the Philippines.

Article. Finduniversity.ph. Retrieved from www.finduniversity.ph/majors/bs-in-electrical-engineering-philippines. Academic American Encyclopedia Vol. 19.Underemployment. Grolier Incorporated 
Danbury, Connecticut p. 383 Academic American Encyclopedia Vol.19.Poor Conditions. Grolier Incorporated

Danbury, Connecticut p.54. Arabit, Edward A. 2001. The Employment Status of the Bachelor of Elementary Education Graduates of Rizal Polytechnic University College. Unpublished Undergraduate Special Problem, URS Morong Rizal.

Avelino, S.E., et. al., Personality Development. Rex Bookstore. Manila Philippines,

1996. Bauzon, P.T. Fundamental Philosophies of Education.Mandaluyong City. National Book Store, 2005.

Brubacher, J.S. Modern Philosophies of Education.Mandaluyong National Bookstore.

Calderon, J. F. Methods of Research and Thesis Writing. National Bookstore. Mandaluyong City,1993.

Compton's Encyclopedia.Vol.7.Unemployment.Compton's Learning Company.

Chicago. P.207

Delos Santos, Jessa S. 2006. Employment Status of BSAgEd Graduates of Laguna State Polytechnic College Siniloan Campus from 1998-2003. Unpublished Undergraduate Special Problem, LSPC, Siniloan, Laguna

Elavazo, A. O. et al. Philosophy of Education. Mandaluyong City. National Booksotre, 1995.

Encyclopedia Americana.Vol. 10.Seeking Employment. Grolier Incorporated. Danbury

Connecticut. U.S.A. p.318

Jugsuart. 1978. Employment and Income of Upper Secondary Vocational School

Graduates in Aytha. Unpublished Thesis. University of the Philippines, Los Baños, Laguna

MOD Magazine. No. 1029. Vol. XXII.1991 Philippines Freepress April 12, 2008, Metro Manila.

Radford, J. Gender and Choice in Education and Occupation.Routledge, London, 1998.Recto, A. S. Foundation of Education Vol. II. Rex Bookstore inc. Metro Manila,

Philippines, 2005.

Sollorano, Crisencio S. 1995. Employment Status of Bachelor of Science Graduates of

LSPCduring the School Year 1991-1992. Unpublished Undergraduate Special Problem, LSPC, Siniloan, Laguna

Sombilla, Ailin F. (2010). Employability of Bachelor of Elementary Education Graduates at Nagcarlan Satellite Campus, Laguna State Polytechnic University Nagcarlan, Laguna AY 2003 - 2008.

\section{A. Internet Sources}

http://nces.ed.gov/pubs2000/2000152.pdf.

hgrmill@sunbeach.net

http://wikieducator.org/images/e/e1/PID_424.pdf

http://driaj2009.blogspot.com/2008/11/graduate-employability-literature.html

http://www.scribd.com/doc/50720521/A-Tracer-Study-of-the-Employment-Status-of-PUPQC-AY-2004-2005) 